\title{
The dimensions of the Greenland Ice Sheet since the Last Glacial Maximum
}

Meredith A. Kelly ${ }^{1}$ and Antony J. Long ${ }^{2}$

'Department of Earth Sciences, Dartmouth College, Hanover, USA; Meredith.A.Kelly@Dartmouth.edu

2Department of Geography, Durham University, UK

\section{The Greenland Ice Sheet survived the warming of the last deglaciation but nonetheless has experienced significant changes in size since the Last Glacial Maximum, thus contributing to global sea level change.}

The Greenland Ice Sheet (Fig. 1) is the only remaining Northern Hemisphere ice sheet that survived the climate warming following the Last Glacial Maximum (LGM; $\sim 22-19 \mathrm{ka}$ ). Nonetheless, it suffered significant changes in size during and since the last deglaciation and has thus made important contributions to global sea level change. A chronology of post-LGM ice sheet extent is important to our understanding of Greenland's contribution to global sea level changes and provides a target against which ice sheet models can be tested (e.g., Tarasov and Peltier, 2002; Fleming and Lambeck, 2004). A long-term

record of Greenland Ice Sheet extent also establishes a baseline for comparison with modern changes, thus yielding insights into the response of the ice sheet over various timescales. Here, we present a brief summary of Greenland Ice Sheet extent during the LGM, deglaciation and the Holocene, highlighting recent research and indicating where data are lacking.

\section{The Greenland Ice Sheet during the LGM and last deglaciation}

During the LGM, in most locations the Greenland Ice Sheet extended offshore, at least onto the continental shelf (Funder,

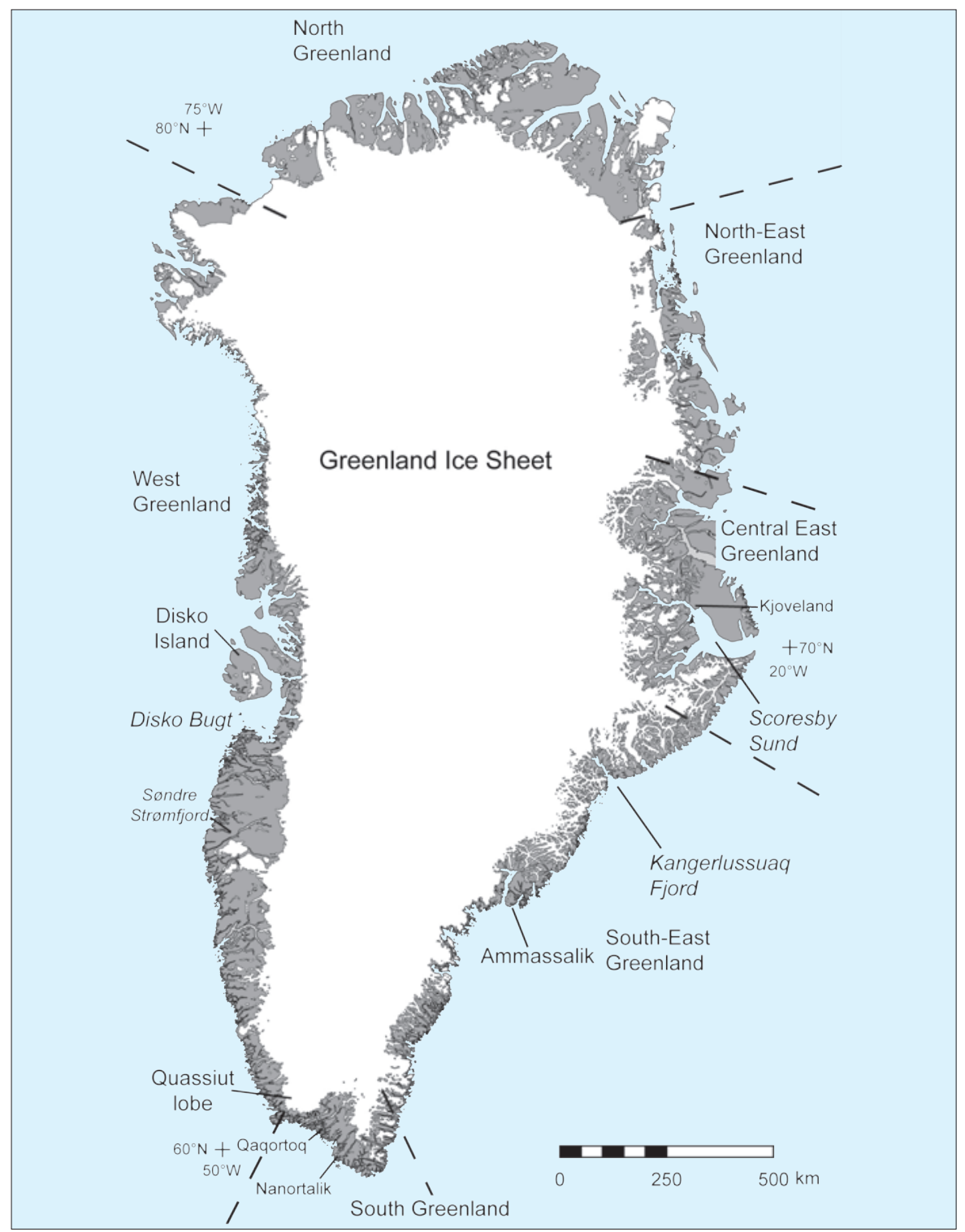

Figure 1: Map of Greenland showing the modern ice sheet extent and locations discussed in the text. Geographical divisions are generally following the Geological Survey of Denmark and Greenland (Dawes and Glendal, 2007). Also shown is Kjoveland, the location of the photo in Figure 2.
1989; Bennike and Björck, 2002). Some debate as to the LGM ice extent exists in locations such as South, Central East and North-East Greenland (e.g., Funder and Hansen, 1996; Bennike and Björck, 2002). However, recent research applying AMS radiocarbon and surface-exposure $\left({ }^{10} \mathrm{Be}\right.$ and ${ }^{26} \mathrm{Al}$ ) dating, as well as ice sheet modeling in South, South-East, Central East and North-East Greenland, indicates that the LGM ice sheet was thick and extended well offshore (Bennike et al., 2002; O'Cofaigh et al., 2004; Roberts et al., 2008; Long et al., 2008; Håkansson et al., 2007a; 2007b).

A few studies register the onset of deglaciation from the LGM extent in offshore areas. For example, radiocarbon ages on foraminifera extracted from sea bed cores from the continental margin off Kangerlussuaq Fjord (South-East Greenland; Fig. 1) show that the ice margin here had begun retreat by $\sim 15$ ka (Meinert et al., 1992). Further data of this type are needed to improve our understanding of the onset of ice margin retreat in other areas, as are surface-exposure ages of ice recession from upper LGM elevations in terrestrial settings (e.g., Rinterknecht et al., 2008). Such data would significantly improve our understanding of the climatic and glaciological conditions that influenced initial deglaciation.

Bennike and Björck (2002) provide a compilation of radiocarbon ages that constrain the timing of ice sheet recession to the present coastline subsequent to the LGM. Most of these radiocarbon ages are on shells from within raised marine deposits and thus afford minimum-limiting ages of local ice margin retreat. Bennike and Björck (2002) suggested that, in all locations except for in South Greenland, ice sheet retreat across the present coastline did not occur until the early Holocene.

Recent terrestrial research in South, South-East and Central East Greenland provides further constraints on the timing of deglaciation to the present coastline. Radiocarbon ages of relative sea level change in the Qaqortoq and Nanortalik areas of South Greenland indicate ice sheet recession by $\sim 11.0 \mathrm{ka}$ and $13.8 \mathrm{ka}$, respectively (Bennike et al., 2002; Sparrenbom et al., 2006a; 2006b). Two recent studies 
using terrestrial data provide the timing of deglaciation in South-East Greenland. Roberts et al. (2008) and Long et al. (2008) report ${ }^{10} \mathrm{Be},{ }^{26} \mathrm{Al}$ and radiocarbon ages from near Ammassalik that date the time of deglaciation in fjords at $\sim 9.9-9.7 \mathrm{ka}$, both at sea level and at higher elevations. Based on the similarity of ages at low and high elevations, the authors suggest that surface ablation controlled rapid deglaciation and ice margin recession. In the Scoresby Sund region (Central East Greenland), radiocarbon and ${ }^{10} \mathrm{Be}$ ages indicate that readvances of Greenland Ice Sheet outlets and mountain glaciers, known as the Milne Land Stages (Funder, 1978), began during late glacial time ( 15-11.5 ka) (Hall et al., 2008a; Kelly et al., 2008). These results imply that at least the outer ford area of Scoresby Sund was ice free prior to late glacial time.

\section{Late glacial \& early Holocene ice sheet readvances and stand-stills}

There is direct chronologic evidence for late glacial readvances of the Greenland Ice Sheet in only one location; central East Greenland. As mentioned above, ice sheet outlets and mountain glaciers in the Scoresby Sund region readvanced during the Milne Land Stages (Funder, 1978). Although some studies suggest that the Milne Land Stages occurred during Preboreal time ( 11.5-10.2 ka) (e.g., Funder and Hansen, 1996), new AMS radiocarbon and ${ }^{10} \mathrm{Be}$ ages suggest that the outer Milne Land Stage moraines were deposited prior to or during the Younger Dryas ( 12.8 $11.5 \mathrm{ka})$, with the inner Milne Land Stage moraines formed during the Preboreal (Hall et al., 2008a; Kelly et al., 2008). Thus, these moraines constrain the ice sheet extent during the Younger Dryas, likely reflecting a response of the ice sheet margin to the late glacial climatic reversal. Other moraines marking ice sheet readvances have been correlated with the Milne Land

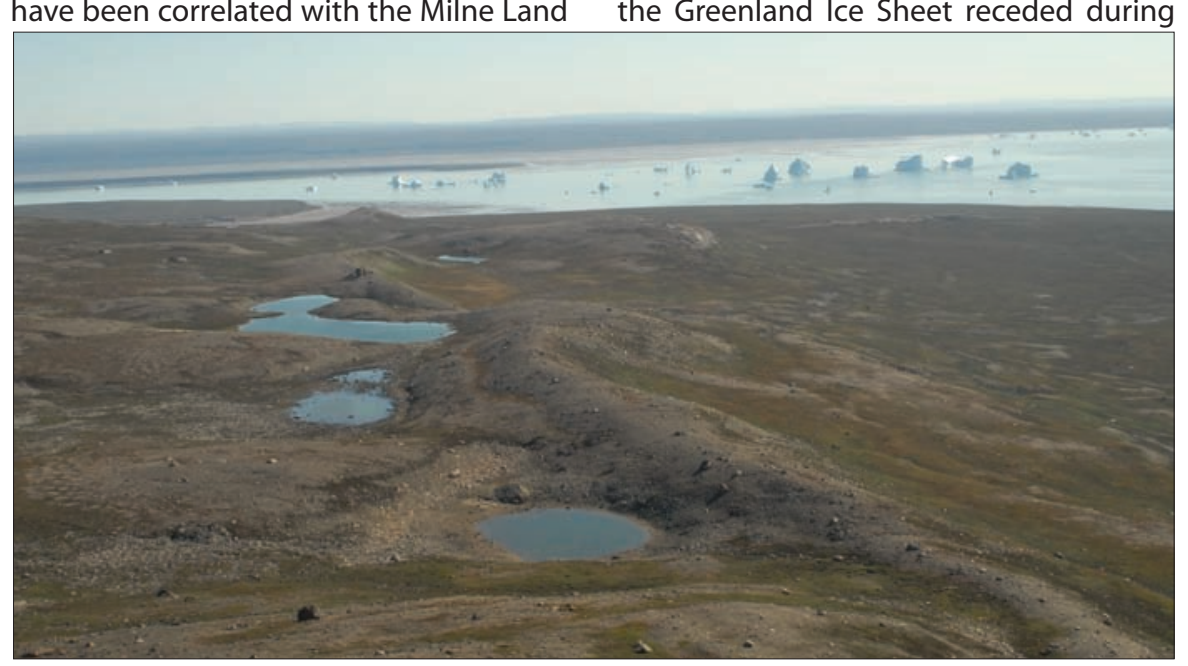

Figure 2: Milne Land stage (left lateral) moraines deposited by a Greenland Ice Sheet outlet glacier prior to or during the Younger Dryas in the Scoresby Sund region of Central East Greenland. View to the east over Kjoveland. the early Holocene, with only minor readvances and stand-stills likely attributed to local topographic influences. There is no direct chronologic evidence for an ice sheet margin response to early Holocene cold events registered by Greenland ice cores, such as the one at $\sim 8.2 \mathrm{ka}$.

\section{The Greenland Ice Sheet during the Holocene}

Based on radiocarbon ages of marine shells and reworked terrestrial organic material incorporated into historical moraines, environmental conditions registered in lacustrine sediments, and submerged coastal features, it has been suggested that the Greenland Ice Sheet receded tens of kilometers within its present day margins during the early and mid Holocene (e.g., Kelly, 1980 and references therein). This ice sheet recession was likely a response to the warmer temperatures of the Holocene Thermal Maximum (9-5 ka) (e.g., Kaufman et al., 2004), which is registered by Greenland ice cores as $\sim 2.5^{\circ} \mathrm{C}$ warmer than at present (Dahl-Jensen et al., 1998). More data are needed to constrain ice sheet dimensions during this interval to cast new light on the stability of the ice sheet in warmer-than-present climatic conditions. A critical question is to determine the dimensions of the ice sheet at the end of this warm interval, prior to the Neoglacial ( 4 ka-present) readvances. In many locations the ice sheet and mountain glaciers reached their maximum extents since the early Holocene during the Little Ice Age (ca. A.D. 1290-1850) (e.g., Kelly, 1980; Hall et al., 2008b; Kelly et al., 2008). Ice-margin fluctuations measured in tens of kilometers characterize the late Holocene dynamics of the Greenland Ice Sheet, and these provide an important baseline against which modern ice sheet fluctuations may be compared.

\section{References}

Bennike, 0. and Björck, S., 2002: Chronology of the last deglaciation of Greenland, Journal of Quaternary Science, 17: 211-219.

Hall, B.L., Baroni, C., Denton, G.H., Kelly, M.A. and Lowell, T.V., 2008a: Relative sea-level Change, Kjove Land, Scoresby Sund, East Greenland: Implications for seasonality in late-glacial time, Quaternary Science Reviews, 27: 2283-2291.

Kelly, M.A., Lowell, T.V., Hall, B.L., Schaefer, J.M., Goehring, B.M., Alley, R.B. and Denton, G.H., 2008: A ${ }^{10}$ Be chronology of late-glacial and Holocene mountain glaciation in the Scoresby Sund region, east Greenland: Implications for seasonality during late-glacial time, Quaternary Science Reviews, 27: 2273-2282

Long, A.J., Roberts, D.H., Simpson, M.J.R., Dawson, S., Milne, G.A. and Huybrechts, P., 2008: Late Weichselian relative sea-level changes and ice sheet history in southeast Greenland, Earth and Planetary Science Letters, 272: 8-18.

Roberts D.H., Long, A.J., Schnabel, C., Freeman, S. and Simpson, M.J.R., 2008: The deglacial history of the southeast sector of the Greenland Ice Sheet during the Last Glacial Maximum, Quaternary Science Reviews, 27: 1505-1516. 